\title{
Pengaruh Budaya dalam Pembentukan Ruang Kota Sala SEJAK PERPINDAHAN KRATON SAMPai DENGAN Peletakan Motif Dasar Kolonial
}

\author{
KUSUMASTUTI \\ Program StUdi PeRENCANAAN Wilayah dan Kota, \\ FAKULTAS TEKNIK \\ UnIVERSITAS SEBELAS MARET, SURAKARTA
}

\begin{abstract}
Kota Surakarta atau sering dikenal dengan sebutan Kota Sala adalah salah satu kota yang pernah mengalami dualisme kepemimpinan antara Kraton Surakarta dan Kolonial Belanda. Hal ini kemudian berpengaruh pada pola-pola bentukan ruang kota yang sampai sekarang masih jelas terlihat di setiap sudut ruang-ruang kotanya, tergambar jelas dalam wujud bangunan sebagai simbol-simbol budaya penguasa saat itu. Menurut Kuntowijoyo, budaya dibedakan menjadi dua, yaitu nilai dan simbol. Nilai merupakan budaya yang tidak kasat mata, sedangkan simbol adalah budaya yang kasat mata dan melibatkan nilai dalam perwujudannya. Tujuan dari penelitian ini adalah untuk mendeskripsikan dan mengkaji pengaruh budaya dalam pembentukan ruang kota sebagai bentuk dari simbol budaya. Metode penelitian menggunakan deskripitf kualitatif. Sehingga analisis dilakukan dengan memaparkan berbagai sumber peta dan tulisan, dan hasil pengamatan di lapangan kemudian hasilnya dideskripsikan. Hasil temuan menunjukkan bahwa dualisme kepemimpinan di Solo sangat berpengaruh pada pola bentukan ruang. Artinya nilai-nilai budaya yang dibawa dari masing-masing penguasa mempengaruhi pola bentukan ruang kotanya yang merupakan wujud dari simbol-simbol budaya penguasa, seperti Beteng Vastenburg merupakan simbol Pemerintah Kolonial dan alun-alun sebagai simbol Kraton Surakarta.
\end{abstract}

Keywords: budaya, kota, kolonial, kraton, ruang

\section{PENDAHULUAN}

Kota Sala adalah salah satu kota besar di Indonesia yang memiliki sejarah panjang dalam perkembangannya. Semenjak terbentuk dari zaman kerajaan hingga sekarang, pertumbuhan dan perkembangan Kota Sala sangat dipengaruhi oleh dinamika pemerintahannya. Dualisme kepemimpinan yang terjadi pada masa kerajaan, yaitu antara Kraton Surakarta dengan Pemerintah Kolonial, menentukan pola bentukan ruang kota dengan unsur nilai dan simbol kebudayaan yang dianut dua penguasa tersebut.

Menurut Kuntjoroningrat, kebudayaan dibedakan menjadi tiga unsur, yaitu ide/ norma, perilaku dan karya/artefak. Sedangkan Kuntowijoyo membedakannya menjadi dua unsur, yaitu nilai dan simbol. Nilai merupakan kebudayaan yang tidak kasat mata, sedangkan simbol merupakan perwujudan nilai yang kasat mata.

Menurut Jo Santoso (2002), kota adalah oikos, yang didalamnya terdapat empat komponen pokok, yaitu humus adalah tempat produksi, home adalah tempat berlindung, homo adalah tempat untuk mengembangkan diri, serta habitat adalah tempat yang digunakan untuk menjalankan proses produksi dan reporoduksi. Sementara itu, kota adalah sebuah sistem yang didalamnya terdiri dari komponen-komponen sistem dengan fungsinya masing-masing untuk mendukung fungsi kota. Maka dapat disimpulkan bahwa keempat komponen oikos tersebut adalah komponenkomponen pembentuk kota yang akan tumbuh dan berkembang seiring dengan pertumbuhan dan perkembangan kota. Tumbuh dan berkembangnya kota terwujud dalam bentuk berbagai macam simbol kebudayaan sebagai perwujudan dari nilai budaya yang dianut oleh penguasanya (pemerintahannya) seperti pola bentuk ruang kota dan bangunan-bangunan yang ada di pusat kota.

Berdasarkan deskripsi di atas maka tujuan dari penelitian ini adalah untuk mendeskripsikan dan mengkaji pengaruh budaya dalam pembentukan ruang kota sebagai bentuk dari nilai dan simbol budaya. 
METODE

Penelitian ini menggunakan metode penelitian deskriptif kualitatif. Menurut Singarimbun (1986), tujuan dari penelitian deskriptif adalah untuk mengetahui perkembangan sarana fisik dan sebaran suatu aspek dari fenomena sosial, dalam penelitian ini adalah pola bentukan ruang dari fenomena dualisme kepemimpinan. Sedangkan penelitian kualitatif adalah suatu prosedur penelitian yang menghasilkan data deskriptif dari obyek yang diamati dengan dasar teori berdasarkan pendekatan fenomenologis dan kebudayaan, dalam penelitian ini adalah fenomena dualisme kepemimpinan yang mempengaruhi pola bentukan ruang.

\section{Metode Pengumpulan Data}

Metode pengumpulan data dilakukan dengan studi literature dan observasi/ pengamatan lapangan. Observasi dilakukan terhadap bentuk ruang Kota Sala dan simbol-simbol kebudayaan yang ada di dalamnya. Sedangkan studi literatur dilakukan terhadap peta-peta dan buku-buku literatur yang berhubungan dengan penelitian, yaitu pada kurun waktu perpindahan kraton sampai dengan peletakan motif dasar Kolonial.

\section{Metode Analisis Data}

Analisis data menggunakan metode kualitatif. Langkah pertama dari analisis data kualitatif adalah melakukan penafsiran data dengan menelaah data-data dari hasil observasi lapangan, peta, gambar dan literatur yang berhubungan dengan simbol dan nilai budaya, serta bentuk ruang Kota Sala sejak perpindahan kraton hingga peletakan dasar motif Kolonial. Data-data tersebut kemudian dikelompokkan sesuai dengan tujuan penelitian, yaitu budaya yang mempengaruhi pembentukan ruang Kota Sala, yaitu pada masa kraton dan pada masa Kolonial Belanda. Setelah itu proses penulisan dilakukan dengan melakukan reduksi terhadap beberapa data yang dianggap tidak relevan dengan tujuan penelitian.

\section{ANALISIS DAN INTERPRETASI Desa Sala, dari Bandar Perdagangan menjadi Oikos}

Pada abad XIII-XIV, ketika Kerajaan Majapahit masih berada pada puncak kejayaannya di Jawa Timur, sungai menjadi alat transportasi utama. Hal tersebut ditunjukkan pula pada gambar 1 bahwa wilayah geografis Desa Sala dikelilingi oleh sungai-sungai kecil sehingga memudahkan bagi para pedagang untuk mendapatkan komoditi perdagangan dari wilayah pedalaman. Pada saat itu, Sungai Bengawan Solo menjadi jalur utama perdagangan dan pelayaran yang menghubungkan antara wilayah pedalaman Jawa (terutama Jawa Tengah) dengan laut serta menjadi jalur pertukaran ekonomi dan peradaban antara wilayah pedalaman dengan dunia luar. Maka tidaklah mengherankan apabila sejarah mencatat bahwa di sepanjang Sungai Bengawan Solo terdapat 44 bandar perdagangan, artinya hal itu menggambarkan betapa kaya wilayah ini sehingga mampu menghasilkan komoditi perdagangan dan menumbuhkan kegiatan perdagangan yang sangat ramai.

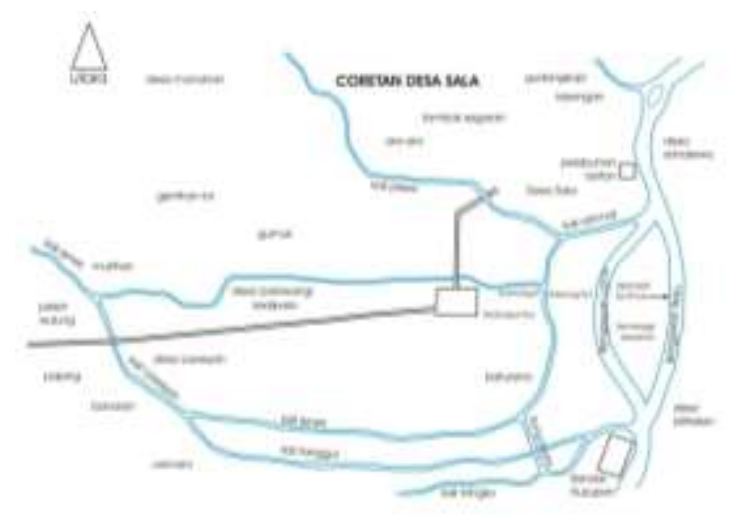

Gambar 1: Peta Desa Sala 1800

(Sumber: Sayid, 1984)

Desa Sala merupakan daerah perdikan yang dikuasai oleh Dinasti Kyai Sala. Di desa ini terletak sebuah bandar perdaganan dibawah kekuasaan dinasti ini. Keramaian perdagangan dan pelayaran di Sungai Bengawan Solo membuat Desa Sala meningkat kesejahteraannya.Interaksi antara masyarakat dengan kaum pendatang yang sebagian besar merupakan kaum pedagang meningkat seiring dengan aktivitas niaga. Para pedagang yang menyusuri sungai sebagai distributor barang-barang dari luar dan menampung produk-produk domestik bukan hanya terdiri atas orang-orang pribumi, akan tetapi juga orang-orang asing seperti Cina, Arab dan Moor. Para pedagang ini sebagai pelaku bisnis aktif dipedalaman Jawa terutama sejak penghancuran pelabuhan-pelabuhan di pesisir Jawa oleh Sultan Agung dan penerapan monopoli oleh VOC (Solo Heritage Society, 2003).

Para pedagang asing yang kemudian melayani perdagangan dan aktivitas niaga disepanjang Sungai Bengawan Solo ini juga memiliki tempat singgah tetap di setiap bandar. Persinggahan tetap ini digunakan oleh mereka apabila harus menunggu persediaan produk yang akan dibawa, menjual habis produk yang diangkut dari daerah hilir maupun untuk menunggu arah angin bagi kepentingan pergerakan perahu mereka. Dalam perkembangan lebih lanjut, lokasi persinggahan itu berubah menjadi perkampungan 
orang asing. Di beberapa bandar sepanjang sungai itu bisa ditemukan sejumlah perkampungan pedagang Cina yang tinggal permanen disana. Di Sala, sejak tahun 1744 telah ditemui adanya komunitas pedagang Cina yang bertempat tinggal disebelah utara Kali Pepe dan menjadi salah satu pusat penting yang memainkan peranan bagi perdagangan didaerah ini dan sepanjang Sungai Bengawan Solo (Solo Heritage Society, 2003).

Komunitas yang terdapat di Desa Sala merupakan perpaduan antara komunitas pedagang dan petani. Para petani tradisional tidak banyak menunjukkan perkembangan, diduga hal ini berkaitan dengan letak Desa Sala yang terletak di tanah yang rendah dan berawa-rawa. Sebelum pusat kekuasan Kerajaan Mataram pindah ke Desa Sala, di desa ini telah ada permukiman, antara lain Kampung Sampangan yang dihuni etnis Madura, Kampung Banjar yang dihuni etnis Banjar Kalimantan, Kampung Kebalen yang dihuni etnis Bali dan Kampung Pasar Kliwon yang dihuni etnis Arab. Oleh karena itu, kehidupan di Desa Sala lebih kuat bercorak desa niaga atau komunitas dagang dibandingkan agraris (Solo Heritage Society, 2003).

Desa Sala, merupakan daerah perdikan, yaitu suatu daerah otonom yang tidak memiliki kewajiban membayar pajak kepada penguasa kerajaan. Penguasa desa perdikan mendapatkan kewenangan memerintah suatu daerah atau wilayah karena jasanya kepada kerajaan di masa lalu. Desa Sala ini karena letaknya di jalur urat nadi perdagangan, memiliki bandar yang sangat ramai dengan kegiatan perniagaan sehingga bandar ini memberikan penghasilan yang sangat besar bagi dinasti yang menguasainya. Namun hal tersebut berubah sejak pusat Kerajaan Mataram berpindah ke Desa Sala. Perpindahan tersebut terjadi karena peristiwa geger Pecinan pada tahun 1741 yang menyebabkan terbakarnya kraton pusat Kerajaan Mataram di Kartosuro. Mitos yang menganggap istana yang sudah dihancurkan oleh musuh tidak lagi pantas dipakai sebagai pusat pemerintahan menyebabkan dipindahkannya pusat Kerajaan Mataram di Kartosuro. Setelah melalui berbagai pertimbangan para penasehat dan ahli nujum serta nasehat dari Kapten VOC maka akhirnya dipilihlah Desa Sala sebagai lokasi keraton yang baru.

\section{Aplikasi Konsep Kota "Kosmologi" Jawa di dalam Kota Sala}

Pada masa kerajaan, Kota Sala merupakan ibu kota baru yang memiliki kekhususan dibanding semua ibu kota kerajaan dari Kota Gede sampai Kartasura. Dilihat dari pola dan morfologi pusat kotanya, Kota Sala tampak meniru pola yang ada di Kartosuro. Ini berbeda dengan Plered dan Kota Gede, karena letak geografisnya, kedua kota ini mengambil Gunung Merapi di utara dan Laut Kidul di selatan sebagai orientasi makrokosmosnya. Di Kartosuro hal ini tidak mungkin, karena lokasinya berada disebelah timur gunung Merapi. Sehingga kemudian dikembangkan sumbu timur-barat yang melintang alun-alun (lor) sejak pusat kota Kartosuro agar tidak kehilangan legitimasi spiritual. Di Kota Sala sumbu timur-barat juga hadir. Meskipun tidak dalam satu garis lurus di tengah alun-alun karena adanya masjid Agung (Adrisijanti,2000).

Tatanan kosmologi kota Kerajaan Surakarta diterangkan oleh Behren (1984) mengikuti pola lingkaran-lingkaran konsentris yang berpusat di Probosuyoso sebagai dalem Raja. Setiap lapis lingkaran diwujudkan dalam bentuk halaman-halaman kraton yang dibatasi oleh regol/kori, yaitu lapis terdalam sampai Srimanganti, berikutnya Kamandungan, kemudian Brajanala, dan terakhir Sitinggil. Lingkar-lingkaran tersebut mencitrakan dunia kosmos. (lihat gambar 3 dan 4).

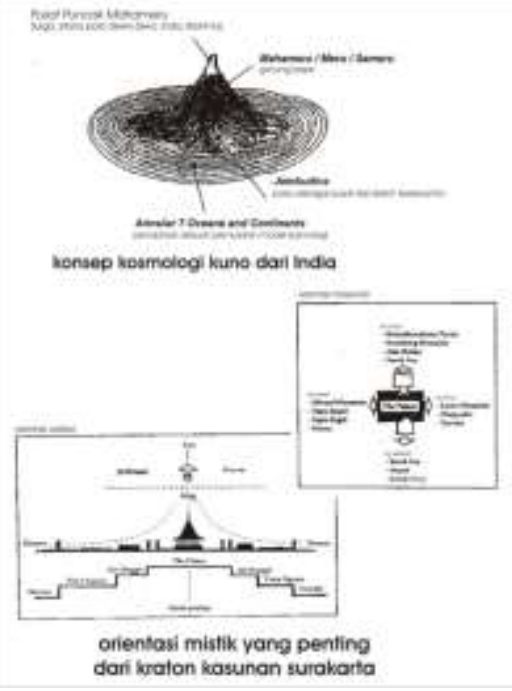

Gambar 2: Konsep Kosmologi di Kraton Surakarta (Sumber:Behrend, 1982, dalam Solo Heritage Society, 2003)

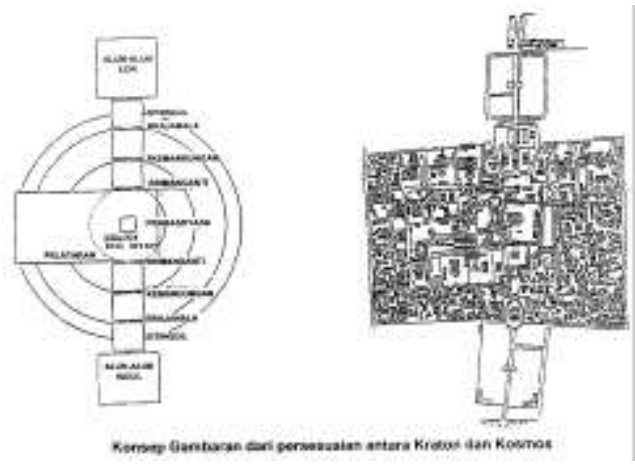

Gambar 3: Gambaran Kosmologi di Kraton Surakarta (Sumber:Behrend, 1982, dalam Solo Heritage Society, 2003) 
Kota Sala sebagai Kota Kolonial dengan "Dual" Konsep Budaya

Kota Sala merupakan sebuah kota yang memiliki peninggalan budaya karena perjalanan sejarahnya sehingga mempengaruhi kebudayaannya. Kuntowijoyo mengatakan, nilainilai budaya selalu hadir dalam setiap perwujudan fisik apakah ruang/bangunan atau konstruksi. Sebuah pabrik, misalnya juga mengandung nilai budaya. Nilai itu ialah efisiensi, kerjasama terorganisasi, pembagian kerja, dan hierarki sosial.

Sejak abad XVI orang-orang Belanda datang ke Indonesia dengan tujuan awal untuk berdagang, tapi pada akhirnya kemudian menjadi penguasa. Belanda mulai menjajah ketika VOC menguasai perdagangan komoditi pertanian di Indonesia yang merupakan komoditi pasar dunia, seperti, lada, vanilla, kopi, gula, nila dan karet. Pada awal kehadirannya, perusahaan dagang Belanda VOC (Vereenigde Oost-Indische Compagnie) mendirikan gudang-gudang (pachuizen) untuk menimbun barang-barang dagangan (rempah - rempah) serta kantor dagang sebagai contoh di Banten, Jepara dan Jayakarta (Jakarta lama). Pada perkembangannya mereka kemudian membuat pengamanan dengan memodifikasi gudang dan kantor tersebut menjadi benteng pertahanan, sekaligus sebagai tempat tinggal warganya. Sistem pertahanan ini dimaksudkan untuk pertahanan dalam bersaing dengan pedagang-pedagang bangsa lain (Soekiman, 2000). Dalam kegiatan perdagangan, VOC tidak hanya menguasai jalur-jalur perdagangan di daerah pesisir Jawa, tetapi mereka juga berusaha menguasai daerah pedalaman. Kebetulan Kerajaan Mataram pada abad XVIIXVIII pusatnya selalu di wilayah pedalaman Jawa dengan wilayah yang sangat luas dan subur. Kegiatan VOC mengintervensi kekuasaan Kerajaan Mataram mulai terasa diwilayah Sala sejak pengambil-alihan Keraton Kartosuro oleh PB II dengan bantuan VOC (kumpeni). Intervensi ini juga meninggalkan jejak sejarah dalam tataruang kota kerajaan yang dibangun kemudian sesudah pusat kerajaan pindah dari Kartosuro ke Desa Sala.

Kecerdikan VOC menerapkan konsep kebudayaan lewat tata ruang Kota Sala menghasilkan sebuah kota konsep "dualism", kota dengan dua konsep kebudayaan, yaitu konsep kota kosmologi Jawa dan konsep kota kolonial (Gambar 5). Hal ini dilakukan untuk menghindari konflik/ peperangan akibat adanya perbedaan budaya. Simbol-simbol budaya dibiarkan berdiri di dalam ruang kota, sementara itu VOC memperkuat cengkeraman kekuasaannya melalui pembangunan-pembangunan infrastruktur pertahanan seperti beteng, jalan militer, barak- barak militer sembari mereka melakukan pelemahan pada sisi kekuasaan kerajaan (tradisional) dengan melalui perjanjian-perjanjian yang tidak adil dan intervensi pada konflikkonflik keluarga keraton bahkan pengaturan kehidupan keluarga raja.

Konsep Kota Kolonial tidak bisa lepas dari budaya kolonial, dimana proses pengambilan keputusan di negara jajahan, terjadi di negara induk. Artinya negara jajahan didominasi oleh sistem nilai, model dan penyelesaianpenyelesaian masalah perkotaan dengan cara masyarakat metropolitan kolonial yang berbeda jauh budayanya dengan masyarakat Sala yang cenderung tradisional.Para perencana kolonial tidak mempedulikan dan cenderung menolak sistem nilai tradisional yang dipegang oleh penduduk pribumi.

Kota-kota yang dikembangkan oleh VOC di Indonesia selalu didasarkan atas suatu konsep yang disebut "founded Settlement" atau cikalbakal permukiman Kolonial Belanda (gambar 4). Konsep ini terdiri atas tata-ruang dan elemenelemen bangunan yang menganut pedoman dan petunjuk teknis yang dikendalikan dari Netherland dan diawasi oleh Gubernur Jendral, Residen serta para insinyur. Hal ini berhubungan dengan konsep kolonialisasi dimana terjadi hubungan dominansi-dependensi. Hubungan ini menunjukkan ketergantungan masyarakat yang dijajah terhadap yang menjajah, akibat penekanan fungsi militer dan administrasi yang dilakukan oleh penjajah.

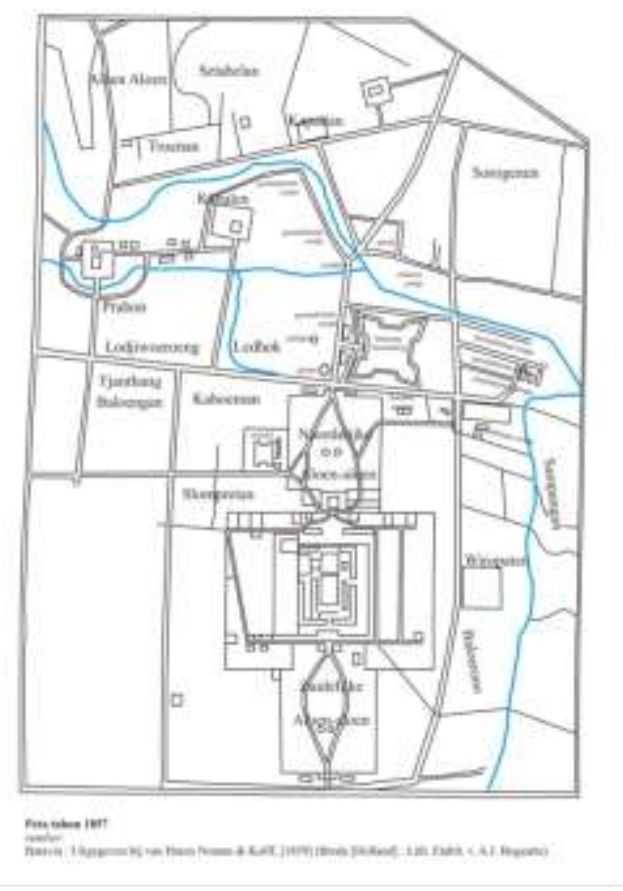

Gambar 4: Rekonstruksi dan Analisis Sejarah Kota

Kolonial di Kota Solo

(Sumber:Solo Heritage Society, 2003) 


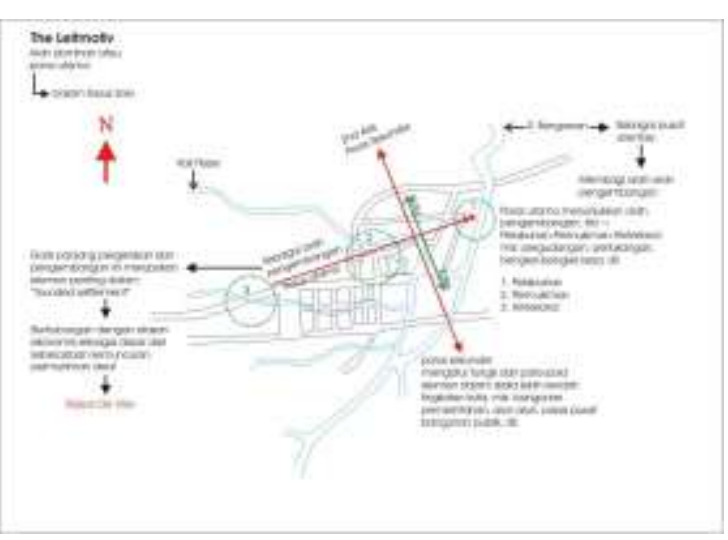

Gambar 5: Peta Kota Sala Tahun 1857: Tata Ruang

Kota dengan Konsep 'dual' Konsep Budaya

(Sumber:Solo Heritage Society, 2003)

\section{KESIMPULAN}

Sejak perpindahan Keraton Mataram dari Kartosuro ke Sala, maka tata ruang Kota Sala tanpa disadari telah terinvensi dengan konsep kota "dualism", kota dengan dua konsep kebudayaan, yaitu konsep kota kosmologi Jawa dan konsep kota kolonial. Penerapan konsep ini tidak lepas dari campur tangan Pemerintah Kolonial untuk menguasai Kota Sala dari segi budaya dengan alasan untuk menghindari konflik/ peperangan akibat perbedaan budaya. Oleh karena itu, simbolsimbol budaya dibiarkan tetap berdiri dalam ruang kota. Konsep kota kolonial menganut pedoman dan petunjuk teknis yang dikendalikan dari Netherland dan diawasi oleh Gubernur Jendral, Residen serta para insinyur. Oleh karena itu, para perencana kolonial tidak mempedulikan dan cenderung menolak sistem nilai tradisional yang dipegang oleh penduduk pribumi dalam mewujudkan ruang kota.

Namun demikian, simbol-simbol budaya keraton tetap terjaga meskipun dalam tataran yang sangat mikro, hanya berada di pusat kota. Orientasi makrokosmos keraton mengambil sumbu utara selatan di utara dan Laut Kidul di selatan. Sementara itu, dalam tatanan kosmologi kota kerajaannya mengikuti lingkaran-lingkaran konsentris yang berpusat di Probosuyoso sebagai dalem Raja. Bentuk ruang kota yang diterapkan keraton ini menunjukkan bahwa hubungan antara rakyat dengan penguasa bersifat simbolik karena rakyat hanya dapat berhubungan dengan rajanya pada peristiwa-peristiwa tradisi budaya. Selebihnya, rakyat hanya menjadi pelayan bagi Raja yang dalam budaya Jawa dianggap sebagai sosok titisan Tuhan.

\section{Daftar Pustaka}

Adrisijanti, Inajati. (2000). Arkeologi Perkotaan Mataram Islam, Jendela: Yogyakarta.

Kuntjoroningrat (1994-edisi 2). Kebudayaan Jawa, Balai Pustaka.

Kuntowijoyo (2002). Selamat Tinggal Mitos Selamat Datang Realitas, Mizan: Bandung.

Sayid, RM. (1984). Babad Sala, Rekso Pustoko: Solo

Santoso, Jo. (2002). (Menyiasati) Kota Tanpa Warga.,Centropolis: Jakarta.

Singarimbun, Masri dan Sofyan Effendi. (1986). Metode Penelitian Survei. Jakarta: Suntingan LP3ES.

Soekiman, Djoko. Prof. Dr. 2000. Kebudayaan Indis dan Gaya Hidup Masyarakat Pendukungnya di Jawa. Yogyakarta: Yayasan Benteng Budaya.

Solo Heritage Society (2003).Sejarah Dan Morfologi Kota Konflik: Dari Periode Kolonial-Orde Baru. (suatu hasil penelitian yang tidak/belum dipublikasikan).

\section{Catatan Kaki}

Seperti disebut pada syair dalam Babad Giyanti, desa Sala merupakan desa yang terletak di dataran rendah dan penuh rawa-rawa. Jenis tanah demikian tidak cocok bagi kegiatan pertanian padi mengingat ancaman banjir dan air yang sulit surut selalu terjadi (Solo Heritage Society, 2003) 
